\title{
40S Ribosomal Protein S19
}

National Cancer Institute

\section{Source}

National Cancer Institute. 40S Ribosomal Protein S19. NCI Thesaurus. Code C29904.

$40 \mathrm{~S}$ ribosomal protein S19 (145 aa, $\sim 16 \mathrm{kDa}$ ) is encoded by the human RPS19 gene. This protein is involved in the maturation of the $40 \mathrm{~S}$ ribosomal subunit and in pre-rRNA processing. 